\title{
PARTISIPASI MASYARAKAT DALAM KEBERLANJUTAN PENGELOLAAN BANK SAMPAH DI DESA SEMAMUNG
}

\author{
Burhanuddin $^{1}$, Hardjito $^{2^{\star}}$, Mega Trishuta Pathiassana ${ }^{3^{*}}$, Rimba Trishuta Pathiussina ${ }^{4}$ \\ ${ }^{1 *}$ Sekolah Pascasarjana Program Studi Manajemen Inovasi Universitas Teknologi Sumbawa \\ 2,3Fakultas Teknologi Pertanian Universitas Teknologi Sumbawa \\ ${ }^{4}$ Fakultas Teknobiologi Universitas Teknologi Sumbawa \\ *Corresponding Author email: ${ }^{1}$ Burhanudin020562@gmail.com 2 hardjito@uts.ac.id, \\ 3mega.trishuta@uts.ac.id, ${ }^{4}$ rimbagt@gmail.com
}

\begin{abstract}
Abstrak
Diterima :

Peran Bank Sampah menjadi penting dengan terbitnya Peraturan Pemerintah (PP)

Bulan Juli 2021

Nomor 8 Tahun 2012 tentang Pengelolaan Sampah Rumah Tangga dan Sampah Sejenis Sampah Rumah Tangga. Bank sampah desa Semamung merupakan bank sampah yang sampai saat ini masih terus aktif dan produktif dibandingkan bank sampah di wilayah Sumbawa lainnya. Oleh karena itu, penelitian ini bertujuan untuk mengetahui partisipasi

Diterbitkan :

Bulan Juli 2021 masyarakat dan faktor-faktor yang memengaruhi tingkat partisipasi masyarakat Desa Semamung, Kabupaten Sumbawa dalam pengelolaan bank sampah. Teknik pengambilan data menggunakan teknik purposive sampling dengan metode kualitatif. Berdasarkan hasil penelitian yang telah dilakukan di Desa Semamung, dari sekitar 478

Keyword :

Bank Sampah, Partisipasi,

Kualitatif,

Purposive

Sampling, Desa

Semamung

Kepala Keluarga (KK), hanya sekitar $18 \mathrm{KK}$ saja yang masih aktif dalam berpartisipasi di Bank Sampah Sahabat Desa Semamung dan faktor yang memengaruhi keikutsertaan masyarakat di program Bank Sampah Sahabat Desa Semamung adalah jumlah anggota keluarga, jenis kelamin, perbedaan usia, dan rendahnya sosialisasi yang dilakukan oleh pengurus Bank Sampah Sahabat Desa Semamung. Penelitian ini menyimpulkan bahwa partisipasi masyarakat Desa Semamung pada program Bank Sampah Sahabat masih relatif sangat rendah.
\end{abstract}

\section{PENDAHULUAN}

Salah satu permasalahan besar yang dialami oleh Indonesia adalah masalah persampahan. Mulai dari pencemaran lingkungan hingga bencana seperti banjir dapat disebabkan oleh sampah. Tumpukan-tumpukan sampah juga merupakan masalah yang tidak bisa dipisahkan dalam kehidupan sehari-hari. Hal ini tidak dapat dipungkiri karena sampah akan selalu ada selama aktivitas kehidupan masih terus berjalan. Volume sampah juga akan selalu bertambah setiap tahunnya seiring dengan pola konsumerisme masyarakat yang semakin meningkat (Suryani, 2014).

Sampah menjadi persoalan pokok di Indonesia khususnya di Nusa Tenggara Barat. Untuk itu diperlukan penanganan oleh masyarakat di wilayah tersebut. Namun, pengolahan sampah hanya dilakukan seperti dengan cara memindahkan, membuang sampah ke sungai, dan membakar sampah sehingga menyebabkan TPA semakin bertambah jumlah volumenya. Kegiatan pengurangan sampah dengan melakukan Reduce, Reuse, dan Recycle (3R) masih mengalami kendala utama, yaitu minimnya peran aktif pemerintah dan permodalan dalam kegiatan operasional, kesadaran masyarakat yang kurang dalam berpartisipasi, serta belum adanya sumber daya manusia yang profesional dalam pengolahan dan pemasaran (Habib, 2019). Partisipasi masyarakat yang sudah memilah sampah sesuai jenisnya sebesar $11,09 \%$, dalam pengolahan sampah sebanyak $50,1 \%$ rumah tangga melakukan pengolahan dengan cara dibakar, $9,7 \%$ rumah tangga membuang sampahnya sembarangan, dan $8,75 \%$ rumah tangga melakukan pemanfaatan terhadap sampahnya (Yuliana dan Wijayanti, 2019).

Salah satu solusi untuk mengatasi masalah sampah, maka dilakukan upaya pengembangan bank sampah karena merupakan penerapan dari 3R sekaligus untuk menumbuhkan kesadaran masyarakat dalam mengelola sampah secara bijak. Bank sampah masih cukup asing untuk individu yang belum merasakan manfaat dari sampah. Peran bank sampah menjadi penting dengan terbitnya Peraturan Pemerintah (PP) Nomor 8 Tahun 2012 tentang Pengelolaan Sampah Rumah Tangga dan Sampah Sejenis Sampah Rumah Tangga yang memberikan regulasi tentang kewajiban produsen untuk melakukan kegiatan 3R dengan cara menghasilkan produk yang menggunakan kemasan yang mudah diurai oleh proses alam, meminimalisasi timbulan sampah, menggunakan 
bahan baku produksi yang dapat didaur ulang dan diguna ulang, serta menarik kembali sampah dari produk dan kemasan produk untuk didaur ulang dan diguna ulang (Sufianti, 2020).

Lokasi yang ingin dikaji penulis terkait bank sampah di Desa Semamung, Kabupaten Sumbawa. Bank Sampah Desa Semamung merupakan bank sampah yang sampai saat ini masih terus aktif dan produktif dibandingkan bank sampah di wilayah Sumbawa lainnya. Oleh karena itu, penelitian ini ingin mengevaluasi partisipasi masyarakat di Desa Semamung yang berperan penting pada keberlanjutan bank sampah yang membantu mengelola sampah di desa tersebut.

\section{LANDASAN TEORI}

Bank Sampah

Definisi dari bank sampah menurut Peraturan Menteri Negara Lingkungan Hidup Republik Indonesia Nomor 13 Tahun 2012 Tentang Pedoman Pelaksanaan Reuce, Reduce, dan Recycle (3R) Melalui Bank Sampah dalam pasal 1 ayat 1 adalah tempat pemilahan dan pengumpulan sampah yang dapat didaur ulang dan atau diguna ulang yang memiliki nilai ekonomi.

Sedangkan menurut Novianty (2013), bank sampah adalah tempat menabung sampah yang telah terpilah menurut jenis sampah dan sampah yang ditabung pada bank sampah adalah sampah yang mempunyai nilai ekonomis. Bank sampah dapat berperan sebagai dropping point bagi produsen untuk produk dan kemasan produk yang habis pakai. Cara kerja dari bank sampah pada umumnya hampir sama dengan bank lainnya seperti ada nasabah, pencatatan pembukuan dan manajemen pengelolaannya, Metode bank sampah juga berfungsi untuk memberdayakan masyarakat agar peduli terhadap lingkungan. Prinsip pelaksanaan pada bank sampah merupakan salah satu rekayasa sosial untuk mengajak masyarakat memilah sampah. Dengan menukarkan sampah dengan uang atau barang berharga yang dapat ditabung, masyarakat akhirnya terdidik untuk menghargai sampah sehingga mereka mau memilah sampah (Amien, 2012).

Dengan keberadaan dari bank sampah dapat menciptakan sebuah momentum awal dalam membina kesadaran pada masyarakat. Pembangunan bank sampah sebenarnya tidak dapat berdiri sendiri tetapi harus disertai integrasi dengan gerakan 3R secara menyeluruh di kalangan masyarakat. Hal ini perlu dilakukan agar manfaat langsung yang dirasakan masyarakat tidak hanya kuatnya ekonomi kerakyatan tetapi juga pembangunan lingkungan yang hijau dan bersih sehingga dapat menciptakan masyarakat yang sehat (Amien, 2012).

Partisipasi Masyarakat
Di dalam kamus besar bahasa Indonesia bahwa partisipasi adalah "perihal turut berperan serta dalam suatu kegiatan (keikutsertaan). Keikutsertaan masyarakat dalam program pengelolaan sampah dapat mengurangi beban kehidupan manusia dan lingkungan dari adanya sampah, masyarakat juga dapat mengolah sampah menjadi barang-barang yang berguna seperti tas, tempat pensil yang memiliki nilai fungsi, selain itu masyarakat juga dapat memperoleh keuntungan ekonomis dari kegiatan pengolahan sampah tersebut (Ratiabriani dan Purbadharmaja, 2016).

Partisipasi masyarakat merupakan keikutsertaan masyarakat dalam menjalankan setiap kegiatan atau program yang telah ditetapkan oleh pemerintah atau lembaga dalam rangka memberdayakan dan membangun masyarakat sehingga masyarakat dapat berperan aktif dalam perencanaan, pelaksanaan dan pemeliharaan (Satria, 2014). Cara yang dapat untuk mengajak atau menumbuhkan partisipasi masyarakat, pada umumnya ada tiga cara, antara lain (Notoatmodjo, 2010):

1. Partisipasi dengan paksaan yang artinya memaksa masyarakat untuk berkontribusi dalam suatu program, baik melalui perundang-undangan, peraturan-peraturan, maupun dengan perintah lisan saja. Cara ini tentunya akan lebih cepat hasilnya dan mudah. Tetapi masyarakat akan takut, merasa dipaksa dan kaget karena dasarnya bukan kesadaran pada diri masyarakat akan tetapi ketakutan. Akibatnya masyarakat tidak akan mempunyai rasa memiliki terhadap program yang ada.

2. Partisipasi dengan persuasi (kesadaran) yang artinya suatu partisipasi yang didasari pada kesadaran. Sukar, tetapi bila tercapai hasilnya akan mempunyai rasa memiliki dan memelihara.

3. Partisipasi dengan edukasi (pendidikan) Partisipasi ini dimulai dengan penerangan, pendidikan dan sebagainya, baik secara langsung maupun tidak langsung.

Tanpa adanya partisipasi masyarakat dalam proses ini, maka dapat dikatakan mustahil pemerintah sendiri bisa mengatasi masalah sampah yang kian hari kian menumpuk. Jika ada partisipasi demikian setidaknya dapat mengurangi beban sampah di TPA, pewadahan dan pengumpulan/pengangkutan dari sumber sampah (Martinawati, dkk, 2016).

\section{Faktor yang Memengaruhi Partisipasi Masyarakat}

Faktor-faktor yang berhubungan dengan partisipasi masyarakat diantaranya adalah sebagai berikut: 
1. Pendidikan

Pendidikan merupakan salah faktor utama dalam yang dapat meningkatkan kualitas sumber daya manusia sehingga dari sumber daya manusia yang berkualitas dapat menciptakan manusia yang produktif yang mampu memajukan bangsa (Langinan et al, 2014). Faktor pendidikan dianggap penting karena dengan melalui pendidikan yang diperoleh seseorang maka seseorang tersebut lebih mudah berkomunikasi dengan orang luar, dan cepat tanggap terhadap inovasi (Slamet, 2014). Tingkat pendidikan memiliki pengaruh terhadap partisipasi masyarakat karena semakin tinggi tingkat pendidikannya maka semakin bertambah pengetahuannya akan pentingnya suatu sehingga semakin tinggi pula tingkat partisipasinya (Hamid, 2013).

2. Pengetahuan

Pengaruh tingkat pengetahuan dengan perubahan perilaku seseoran akan membuat penyampaian informasi semakin baik oleh pihak terkait, maka perubahan perilaku akan semakin bermakna (Slamet, 2014). Pengetahuan memiliki hubungan yang signifikan terhadap kegiatan pengelolaan sampah padat yang dilakukan masyarakat. Masyarakat tentunya akan memiliki kesadaran terhadap pentingnya program pengelolaan sampah, dikarenakan dampak yang akan dihasilkan oleh sampah tersebut jika tidak dikelola dengan baik. Apabila seseorang memiliki banyak pengetahuan maka seseorang tersebut akan memikirkan akibat dari kegiatan pengelolaan sampah itu sendiri (Laor, dkk, 2018).

3. Jenis Kelamin

Seorang pria dan wanita dalam pembangunan tentunya akan memiliki tingkat partisipasi yang berbeda. Hal ini disebabkan oleh adanya sistem pelapisan sosial yang terbentuk dalam masyarakat, yang membedakan kedudukan dan derajat antara pria dan wanita. Perbedaan kedudukan dan derajat ini, akan menimbulkan perbedaan-perbedaan hak dan kewajiban antara pria dan wanita (Slamet, 2014). Pada penelitian sebelumnya yang dilakukan Tanod, dkk (2014) dijelaskan bahwa wanita lebih banyak berurusan dengan pengelolaan sampah daripada pria. Hal tersebut disebabkan karena wanita sebagai ibu rumah tangga, dan wanita sering berada di dapur yang merupakan salah satu tempat penghasil sampah rumah tangga.

4. Usia

Tingkat partisipasi masyarakat juga dipengaruhi oleh perbedaan usia. Terdapat perbedaan antara kedudukan dan derajat pada masyarakat atas dasar senioritas, sehingga akan memunculkan golongan tua dan golongan muda, yang berbeda-beda dalam hal-hal tertentu. Perbedaan usia menyebabkan perbedaan jenis partisipasi yang diberikan, seperti golongan tua akan lebih banyak memberikan pendapat dibandingkan dengan golongan muda yang lebih aktif bekerja di lapangan (Slamet, 2014).

5. Pekerjaan

Pekerjaan akan berkaitan erat dengan tingkat penghasilan seseorang. Dengan demikian dapat disimpulkan bahwa mata pencaharian seseorang dapat mempengaruhi partisipasi masyarakat dalam pembangunan. Hal ini disebabkan karena pekerjaan akan berpengaruh pada kesibukan seseorang yang akan menentukan waktu luang seseorang untuk terlibat dalam pembangunan, misalnya dalam hal menghadiri pertemuan, kerja bakti dan sebagainya (Slamet, 2014). Jenis pekerjaan seseorang berkaitan yang kuat dengan tingkat peran serta masyarakat karena berhubungan erat dengan kesempatan atau waktu luang yang ada untuk menghadiri kegiatan dengan warga yang lain.

6. Pendapatan atau Penghasilan

Pendapatan pada suatu keluarga juga bisa mempengaruhi tingkat partisipasi masyakat. Pendapatan keluarga adalah pendapatan yang diperoleh dalam waktu satu bulan oleh suatu keluarga yang digunakan oleh keluarga tersebut untuk memenuhi kebutuhan hidup seluruh anggota keluarga (Ratiabriani dan Purbadharmaja, 2016). Menurut Yadnya (2005) dalam Ratiabriani dan Purbadharmaja (2016), menyebutkan bahwa pendapatan keluarga memiliki pengaruh positif dan nyata terhadap partisipasi masyarakat, semakin tinggi pendapatan yang diperoleh oleh masyarakat tersebut maka semakin tinggi pula tingkat partisipasinya. Tingkat pendapat juga mempengaruhi partisipasi masyarakat, yaitu penduduk yang lebih kaya kebanyakan membayar pengeluaran tunai dan jarang melakukan pekerjaan fisik sendiri untuk pengelolaan sampahnya. Sementara penduduk yang berpenghasilan paspasan akan cenderung berpartisipasi dalam hal tenaga. Besarnya tingkat penghasilan akan memberi peluang lebih besar bagi masyarakat untuk berpartisipasi. Masyarakat hanya akan bersedia untuk mengerahkan semua kemampuannya apabila hasil yang dicapai akan sesuai dengan keinginan dan prioritas kebutuhan mereka (Slamet, 2014).

7. Jumlah Anggota Keluarga

Jumlah anggota keluarga juga berpengaruh dalam partisipasi masyarakat. Semakin banyak anggota keluarga maka semakin besar 
pula kebutuhan dalam keluarga tersebut begitu juga sebaliknya apabila dalam suatu keluarga memiliki anggota keluarga yang sedikit maka semakin sedikit pula kebutuhan yang dipenuhi sehingga apabila semakin banyak anggota keluarga maka akan lebih berpatisipasi untuk memenuhi banyaknya kebutuhan yang harus dipenuhi di keluarganya (Adiana dan Karmini, 2012).

8. Sarana dan Prasarana Pengelolaan Sampah.

9. Wadah sampah

Wadah sampah adalah tempat yang digunakan untuk menyimpan sampah sementara di sumber sampah. Kriteria wadah sampah diuraikan dalam SNI No. 19-2454-2002 tentang Tata Cara Teknik Operasional Pengelolaan Sampah Perkotaan adalah sebagai berikut:

a) Tidak mudah rusak dan kedap air.

b) Ekonomis dan mudah diperoleh atau dibuat oleh masyarakat.

c) Mudah dikosongkan

Sarana pengelolaan sampah merupakan salah satu faktor yang memengaruhi partisipasi masyarakat dalam sebuah kegiatan. Keberadaan sarana dan prasarana merupakan faktor penting yang dapat menunjang jalannya proses pengelolaan sampah. Kemudahan yang didapatkan dengan adanya sarana dan prasarana dalam proses pemilahan sampah akan membuat masyarakat termotivasi untuk melaksanakan kegiatan pengelolaan sampah melalui program bank sampah (Tansatrisna, 2014)

\section{METODE PENELITIAN}

\section{Lokasi Penelitian}

Pada penelitian ini, survei dilakukan di Desa Semamung, Moyo Hulu. Desa Semamung merupakan salah satu desa dari 12 desa di wilayah Kecamatan Moyo Hulu. Desa Semamung mempunyai luas wilayah seluas $22,48 \mathrm{~km}^{2}$ atau 2.248 hektar. Jumlah Penduduk Desa Semamung per September 2020 adalah sebanyak 1.902 jiwa, dengan 878 orang laki-laki dan 1.024 orang perempuan. Obyek dalam penelitian ini dilakukan kepada Pengelola Bank Sampah Sahabat yang berasal dari Desa Semamung, Kabupaten Sumbawa.

\section{Pendekatan dan Jenis Penelitian}

Penelitian ini menggunakan metode deskriptif kualitatif. Metode yang digunakan adalah metode deskriptif analisis, yaitu penelitian yang berusaha menggambarkan suatu permasalahan yang dikaji mengenai fenomena. Metode ini digunakan untuk mendeskripsikan atau menjelaskan peristiwa yang ada pada masa sekarang, termasuk dalam metode ini adalah studi kasus, survey, studi pengembangan dan studi korelasi. Penelitian deskriptif merupakan penelitian yang dimaksudkan untuk mengumpulkan informasi mengenai status suatu gejala yang ada, yaitu keadaan gejala menurut apa adanya pada saat penelitian dilakukan. Seperti halnya penelitian model Pengukuran Sesudah Kejadian (PSK), penelitian deskriptif tidak memerlukan administrasi atau pengontrolan terhadap sesuatu perlakuan (Arikunto 2010).

Penelitian deskriptif adalah sebuah penelitian yang lebih luas dalam penggunaan datadatanya dan metode riset yang memiliki tujuan guna menjelaskan secara spesifik peristiwa sosial dan alam. Kespesifikan pengunaan teori inilah menyebabkan alasan bahwa penelitian deskriptif bisa mempergunakan data berupa angka-angka yang ada dalam penelitian kuantitatif dan kata-kata yang lebih condong dalam penelitian kualitatatif. Pada penelitian ini, survei ini dilakukan kepada masyarakat Desa Semamung Kabupaten Sumbawa.

\section{Populasi dan Informan Peneliti}

Definisi populasi adalah wilayah generalisasi yang terdiri atas objek atau subjek yang mempunyai kualitas dan karakteristik tertentu yang ditetapkan oleh peneliti untuk dipelajari dan kemudian ditarik kesimpulannya (Sugiyono, 2016). Informan dalam penelitian kualitatif, yaitu informan penelitian yang memahami informasi tentang obyek penelitian. Informan yang dipilih harus memiliki pertimbangan agar informasi yang didapatkan harus bermanfaat untuk penelitian yang dilakukan. Terdapat pertimbangan untuk menentukan informan penelitian yang dikatakan oleh para ahli.

Informan penelitian adalah orang yang di manfaatkan untuk memberikan informasi tentang situasi dan kondisi latar belakang penelitian dan merupakan orang yang benar-benar mengetahui permasalahan yang akan di teliti (Moleong, 2014)

Dengan kata lain unit sampel yang dihubungi disesuaikan dengan kriteria-kriteria tertentu yang diterapkan berdasarkan tujuan penelitian. Maka dari itu peneliti menentukan informan yang memenuhi kriteria tersebut. Informan yang peneliti tentukan merupakan Pengurus BumDes Sahabat, Struktur Pengelola bank sampah dan Masyarakat Desa Semamung.

Setelah melakukan sesi wawancara, nantinya peneliti akan mereduksi pembahasan tentang analisis bank sampah Desa Semamung, maka peneliti melakukan wawancara kepada 7 informan yang terdiri dari 2 informan dari pihak desa, 1 informan dari pihak Bumdes/penggelola Bank Sampah Sahabat, 1 Ketua Karang Taruna dan 3 infoman pendukung dari pihak masyarakat Desa Semamung. 


\begin{tabular}{clc} 
NO & \multicolumn{1}{c}{ NAMA } & \multicolumn{1}{c}{ POSISI } \\
\hline 1 & Rudi Mustaid & Kepala Desa \\
\hline 2 & Hendra & Sekretaris Desa \\
\hline 3 & Putri Munira & Bendahara BumDes \\
\hline 4 & Mastar & Masyarakat \\
\hline 5 & Jundi Khairullah & Masyarakat \\
\hline 6 & Eni & Masyarakat \\
\hline 7 & A.M. Mikail & Ketua Karang Taruna \\
\hline
\end{tabular}

\section{Prosedur Pengumpulan Data}

Metode pengumpulan data yang digunakan dalam penelitian ini adalah:

\section{Observasi}

Observasi adalah pengamatan yang dilakukan secara langsung kepada suatu objek yang diteliti. Observasi dalam penelitian ini, yaitu dengan memilah data subjek melalui basis data yang dimiliki.

2. Wawancara

Wawancara adalah suatu percakapan yang diarahkan pada suatu masalah tertentu dan merupakan proses tanya jawab lisan di mana dua orang atau lebih berhadapan secara fisik. (Gunawan, 2013). Dari wawancara ini, peneliti akan memperoleh informasi spontan dan mendalam dari setiap informan.

Tipe wawancara yang digunakan, yaitu wawancara semi terstruktur di mana tetap dalam prosedur pertanyaan wawancara akan tetapi bisa menggali lebih dalam dari pihak informan. Ukuran dari sampel yang akan dijadikan obyek penelitian ditentukan dengan pendekatan purposive sampling adalah salah satu jenis teknik pengambilan sampel yang biasa digunakan dengan menentukan kriteriakriteria tertentu sebelum dilakukan pengumpulan data.

Dalam wawancara informan, seorang pewawancara harus memiliki kejujuran, kesabaran, rasa empati, dan semangat yang tinggi dengan tujuan untuk menghasilkan data valid yang dibutuhkan. Wawancara mendalam dilakukan dengan mempersiapkan sejumlah daftar pertanyaan. Umumnya wawancara lapangan ini memiliki karakteristik awal dan akhir yang tidak terlihat jelas. Pertanyaan yang diajukan disesuaikan dengan kondisi dan situasi di lapangan. Wawancara lebih banyak bersifat informal dan fleksibel, mengikuti norma yang berlaku pada setting lokal, kadang diselipkan dengan canda-tawa yang dapat mencairkan suasana dan membina hubungan yang erat serta meningkatkan kepercayaan individu yang diteliti.

Dalam wawancara, peneliti menetapkan dimulai dari structural tertinggi hingga bawah guna mendapatkan informasi, dengan melihat dimana titik jenuh /dari informasi yang didapatkan oleh peneliti dengan menelaah 5 sampai 7 informan terakhir sama jawaban nya. Di mana peneliti memulai dari informan kunci, yaitu pengurus Bumdes Sahabat, dan ketua pengelola bank sampah Desa Semamung, dimana peneliti mendapatkan informasi detail dalam mencari datanya, dan ditambah informan pendukung yang bisa diarahkan oleh informan kunci demi mendukung hasil dari informan kunci.

\section{HASIL DAN PEMBAHASAN}

\section{Produksi Sampah di Desa Semamung}

Dari wawancara terhadap pemerintah dan masyarakat Desa Semamung ada banyak hal yang menjadi perhatian terhadap sampah ini. Sesuai pernyataan yang disampaikan oleh Bapak Hendra selaku Sekretaris Desa, bahwa sebagian besar masyarakat Desa Semamung masih sering membuang sampah di area sungai yang justru mengakibatkan sampah berserakan di sekitar aliran sungai, sehingga mengganggu pemadangan dan kebersihan di sekitar wilayah aliran sungai. Hal ini disebabkan oleh tidak tersedianya lokasi Tempat Pembuangan Akhir (TPA) untuk membuang sampah masyarakat. Selain itu, pengelolaan sanitasi desa juga relatif masih kurang baik, sehingga tidak adanya sistem pembuangan limbah yang cukup memadai bagi masyarakat desa. Rata-rata sampah non organik yang dihasilkan oleh masyarakat Desa Semamung adalah sekitar 0,5-1 kg per harinya dalam setiap Kepala Keluarga (KK). Sedangkan, jumlah sampah organik yang dihasilkan dapat mencapai sekitar 1-1,5 kg per harinya.

Kemudian, perilaku masyarakat yang terbiasa membakar sampah non organik juga dapat menyebabkan permasalahan lingkungan seperti pencemaran atau polusi udara yang dapat berakibat pada kesehatan berupa gangguan pernapasan, penyakit jantung, kanker berbagai organ tubuh, gangguan reproduksi, dan hipertensi (PTM Kabupaten Pringsewu, 2019). Hal ini dikarenakan pembakaran sampah, terutama plastik, akan menghasilkan zat-zat berbahaya, seperti karbon monoksida, hidrokarbon benzopirena, dan dioksin (Kum, 2020).

Saudara A.M. Mikail, selaku Ketua Karang Taruna, juga menyampaikan bahwa pengelolaan sampah diharapkan dapat segera diwujudkan di Desa Semamung. Hal ini bertujuan agar masalah-masalah yang ada di Desa Semamung dan disebabkan oleh sampah akan segera teratasi, sehingga permasalahan-permasalahan akibat dari sampah yang berkaitan dengan kesehatan dan lingkungan semakin berkurang dari waktu ke waktu.

\section{Partisipasi Masyarakat}

Dari sekitar 478 Kepala Keluarga (KK), diketahui bahwa hanya sekitar 18 KK saja yang masih aktif dalam berpartisipasi di Bank Sampah 
Sahabat Desa Semamung. Hal ini berarti hanya sekitar 3,77\% saja dari total KK yang ada di Desa Semamung yang telah menyambut dengan antusias program yang dilakukan oleh bank sampah tersebut. Diketahui pula rasa gengsi masyarakat masih cukup tinggi jika harus membawa sampah/mengambil limbah yang sudah tidak layak untuk dikumpulkan lalu dipilah dan disetorkan kepada bank sampah. Disampaikan pula oleh Ibu Eni, bahwa ketika program ini berjalan dan ada petugas yang setiap harinya datang untuk mengambil sampah, maka masyarakat nantinya juga akan akan mulai termotivasi untuk melakukan perubahan lingkungan yang akan membawa dampak yang sangat bagus untuk keindahan mata dan segarnya lingkungan desa ketika masyarakatnya peduli dengan kesehatan.

Dalam upaya menarik perhatian masyarakat di Desa Semamung terhadap keikutsertaan mereka pada program-program Bank Sampah Sahabat, pihak pengelola juga pernah memberikan bingkisan sembako. Tidak hanya pihak pengelola, tetapi juga Kepala Desa Semamung berharap agar Desa Semamung dapat menjadi desa percontohan yang dapat memecahkan masalah pengolahan limbah rumah tangga, baik organik maupun non organik. Oleh karena itu, peran seluruh lapisan masyarakat dibutuhkan untuk mewujudkan cita-cita lingkungan yang bersih dan sehat melalui bank sampah, salah satunya tentu peran para pemuda.

Sarana dan prasarana penunjang seperti ketersediaan bak atau tong sampah yang disediakan untuk masyarakat juga dapat menjadi pendorong bagi peningkatan partisipasi masyarakat dalam program bank sampah. Hal ini dikuatkan dengan ketersediaan tempat sampah sesuai dengan karakteristik atau jenis sampah berpengaruh terhadap pasrtisipasi masyarakat dalam melakukan pemilahan sampah (Maulina, 2012). Ketersediaan tempat sampah juga memiliki hubungan yang signifikan dengan partisipasi masyarakat dalam program bank sampah (Manalu, dkk, 2013)

Jumlah yang sedikit tidak menjadikan program desa ini terhenti. Setidaknya dengan sedikitnya anggota nantinya dapat menjadi pemicu bagi masyarakat lainnya untuk turut andil dalam program ini. Program ini merupakan salah satu program unggulan Pemprov NTB yang berhubungan dengan Program Bebas Sampah atau Zero Waste Program. Karenanya, peluang bagi desa untuk mengembangkan bank sampah tersebut cukup besar. Bank sampah juga diharapkan dapat menjadi salah satu sumber pendapatan baru pula bagi masyarakat desa nantinya.

Bapak Mikail (Ketua Karang Taruna) menyampaikan, bahwa masyarakat juga masih menunggu program yang lebih inovatif dari pengelola bank sampah agar nantinya dapat menjadi insentif bagi masyarakat untuk lebih berpartisipasi dalam program bank sampah. Insentif ini bukan lagi hal-hal yang bersifat sementara atau sporadis seperti pembagian sembako yang sebelumnya pernah dilakukan, tetapi lebih bersifat jangka panjang. Sehingga, masyarakat dapat mengubah paradigmanya mengenai sampah yang biasanya hanya sesuatu yang tidak bernilai dan harus segera dibuang, tetapi menjadi sesuatu yang dapat berubah nilainya asalkan mendapatkan perlakuan yang tepat. Disampaikan juga kembali oleh Bapak Jundi, bahwa masyarakat akan tergerak jika program yang direncanakan dapat memperlihatkan hasil yang nyata, terutama mengenai insentifnya. Sehingga, partisipasi masyarakat ke depannya juga akan semakin meningkat.

\section{Faktor yang Memengaruhi Partisipasi Masyarakat}

Kenaikan dan penurunan dari jumlah partisipasi masyarakat merupakan hal yang cukup lumrah dihadapi oleh bank sampah yang tengah dikelola. Hal ini dapat dipengaruhi oleh beberapa faktor yang terjadi di antara masyarakat. Faktor pertama yang memengaruhi keikutsertaan masyarakat di program Bank Sampah Sahabat Desa Semamung adalah jumlah anggota keluarga. Semakin banyaknya jumlah anggota keluarga yang ada, dapat menghasilkan jumlah sampah yang relatif lebih banyak. Sehingga, hal ini dapat mendorong masyarakat untuk mengikuti program pemilahan sampah di Bank Sampah Sahabat. Sebab, ketika sampah semakin banyak, maka beban akan semakin bertambah dan membutuhkan tenaga yang lebih banyak lagi untuk mengelola sampahsampah tersebut. Jika bank sampah dapat menyediakan sistem pengelolaan sampah yang relatif mudah, bersih, dan sehat, maka antusiasme masyarakat untuk berpartisipasi pun akan semakin meningkat.

Alasan mengenai jumlah anggota keluarga merupakan faktor yang memengaruhi juga, bahwa semakin banyak anggota keluarga, maka akan semakin besar pula kebutuhan dalam keluarga tersebut, begitupun sebaliknya (Adiana dan Karmini, 2012). Sehingga, apabila semakin banyak anggota keluarga, maka akan lebih berpatisipasi untuk memenuhi banyaknya kebutuhan yang harus dipenuhi keluarganya. Harapan dari masyarakat yang memiliki jumlah anggota dengan jumlah kebutuhan yang relatif tinggi agar mereka dapat memperoleh tambahan pendapatan dari kegiatan bank sampah. Partisipasi masyarakat juga dipengaruhi oleh salah satu faktor internal individu berupa motivasi untuk mendapatkan keuntungan dan manfaat atas partisipasinya tersebut pada sebuah kegiatan (Nurbaiti, 2017). Manfaat yang didapatkan dari bank sampah berhubungan 
signifikan dengan partisipasi masyarakat dalam mengikuti program tersebut (Manalu, 2013). Keuntungan ekonomi yang didapatkan masyarakat memengaruhi partisipasi masyarakat dalam melakukan pengelolaan sampah (Posmaningsih, 2016).

Tingkat partisipasi untuk setiap anggota masyarakat berlainan satu sama lain sesuai dengan kemampuan dan karakteristik mereka masingmasing. Partisipasi dalam pengambilan keputusan mengenai proses atau program yang akan dilakukan oleh bank sampah juga dapat memengaruhi tingkat partisipasi masyarakat dalam bank sampah. Proses pengambilan keputusan tersebut dapat digunakan untuk menampung semua gagasan dan ide yang dapat dieksekusi oleh pengelola nantinya. Hal ini turut berperan dalam menigkatkan rasa memiliki (sense of belonging) masyarakat desa terhadap bank sampah yang ada di Desa Semamung. Ketika rasa memiliki menjadi bertambah besar, maka dorongan untuk ikut memajukan program-program yang diselenggarakan juga akan semakin besar. Wujud lain dari partisipasi dalam pengambilan keputusan, antara lain ikut menyumbangkan gagasan atau pemikiran tentang membentuk bank sampah, kehadiran dalam rapat, diskusi, dan tanggapan atau penolakan terhadap program bank sampah (Saputro, 2015; Tanuwijaya, 2016).

Selanjutnya Bendahara Bumdes
Semamung menyampaikan, bahwa timnya dalam bank sampah akan mengupayakan pengelolaan sampah terpadu yang terdiri dari pengolahan sampah organik menjadi pakan atau pellet bagi ternak unggas dan ikan, serta mengusahakan pengadaan alat pencacah plastik untuk diolah menjadi bijih plastik yang akan langsung disalurkan kepada para pengusaha yang membutuhkan bahan baku berupa bijih plastik. Semua ini direncanakan akan terealisasi dalam jangka waktu satu tahun ke depan.

Sosialisasi mengenai program, tata cara memilah sampah, prosedur menabung dan tipe-tipe sampah yang diterima oleh bank sampah sangatlah diperlukan. Ketua Karang Taruna Desa Semamung juga menyampaikan bahwa selama ini yang cukup terdengar di masyarakat bukanlah kegiatan sosialisasi atau pelatihan yang diselenggarakan oleh bank sampah kepada masyarakat secara langsung, tetapi hanya berupa berita di media yang menurut pernyataannya tidak seperti hasil yang diberikan.

Peran pemerintah dan tokoh masyarakat berkaitan dengan sosialisasi dan penyebaran informasi mengenai bank sampah juga sangat dibutuhkan. Terlebih lagi bahwa karakteristik masyarakat kebanyakan hanya akan patuh kepada orang yang mereka hormati. Oleh sebab itu, pengelola bank sampah juga harus berupaya untuk berkolaborasi dan berkoordinasi dengan pihakpihak terkait yang dapat menjadi solusi pula bagi peningkatan partisipasi masyarakat. Pemerintah dan tokoh masyarakat sangat berperan sebagai motivator dan fasilitator yang memberikan pendampingan kepada masyarakat baik dalam edukasi maupun pelaksana teknis bank sampah (Maulina, 2012). Di Denpasar menunjukan, bahwa kampanye program dan pelatihan pemisahan sampah yang dilakukan oleh pemerintah setempat juga berpengaruh terhadap partisipasi masyarakat dalam melakukan pemisahan dan daur ulang sampah (Posmaningsih, 2016).

Faktor jenis kelamin juga menentukan tingkat partisipasi dari masyarakat. Kebanyakan dari masyarakat yang berpartisipasi dalam kegiatan bank sampah adalah perempuan. Sedangkan, untuk laki-laki biasanya lebih mempercayakan pengelolaannya kepada para perempuan yang ada di rumahnya. Hal ini bisa jadi dapat dikarenakan dengan adanya pembagian peran domestik yang ada di setiap rumah tangga masing-masing masyarakat. Perempuan lebih banyak berurusan dengan pengelolaan sampah daripada para lakilaki, hal tersebut disebabkan karena sebagai ibu rumah tangga, perempuan lebih sering berada di dapur yang merupakan salah satu tempat penghasil sampah rumah tangga yang utama (Tanod, dkk, 2014). Sama halnya dengan yang terjadi di Bank Sampah Sahabat, baik dari pengelola maupun partisipasi, lebih banyak perempuan yang ikut berperan aktif.

Perbedaan usia juga memengaruhi tingkat partisipasi masyarakat. Hal ini menyebabkan perbedaan jenis partisipasi yang dapat pula dipengaruhi oleh sikap senioritas atau kebiasaan di wilayah setempat. Misalnya, golongan tua akan lebih banyak memberikan pendapat dibandingkan dengan golongan muda yang lebih aktif bekerja di lapangan (Slamet, 2014). Di Desa Semamung sendiri, biasanya yang ikut berperan sebagai pengelola dan relawan rata-rata masih berusia remaja hingga dewasa.

Selanjutnya, pengetahuan merupakan faktor yang juga berpengaruh pada tingkat partisipasi masyarakat dalam pengelolaan sampah melalui Bank Sampah Sahabat. Masyarakat yang memahami fungsi dan peran bank sampah yang berdampak besar pada kebersihan lingkungan dan kesehatan akan lebih termotivasi untuk berpartisipasi dalam kegiatan-kegiatan bank sampah. Namun, bagi masyarakat yang masih memiliki pengetahuan yang minim mengenai hal tersebut akan cenderung menarik diri dan tetap membuang sampah di sembarang tempat. Pengetahuan sendiri merupakan informasi yang diketahui atau disadari oleh seseorang dan telah dikombinasikan dengan pemahaman dan potensi untuk menindaki yang lantas melekat di benak 
seseorang (Slamet, 2014). Pada umumnya, pengetahuan memiliki kemampuan prediktif terhadap sesuatu sebagai hasil pengenalan atas suatu pola. Manakala informasi dan data sekedar berkemampuan untuk menginformasikan atau bahkan menimbulkan kebingungan, maka pengetahuan berkemampuan untuk mengarahkan tindakan.

\section{Dampak Sosial, Ekonomi, dan Lingkungan dari Bank Sampah Sahabat}

Ada beberapa dampak yang dihasilkan dengan didirikannya Bank Sampah Sahabat di Desa Semamung. Jika disesuaikan dengan konsep pembangunan berkelanjutan, maka dampak yang dihasilkan dapat dilihat dari 3 aspek, sebagai berikut:

a. Dampak Sosial

Para informan mengakui bahwa keberadaan bank sampah saat ini, meskipun belum maksimal dalam mencapai target yang diinginkan, tetapi cukup membantu dalam mengedukasi masyarakat mengenai pentingnya memilah sampah. Selain itu, pengolahan dan pemanfaatan kembali sampah menjadi produk yang baru juga turut menciptakan interaksi positif di antara masyarakat yang terlibat.

b. Dampak Ekonomi

Menurut beberapa informan dari kalangan masyarakat, bank sampah memang memberikan tambahan pendapatan bagi mereka, akan tetapi jumlah pendapatan yang diterima masih relatif sangat kecil, sehingga manfat ekonomi yang didapat belum terlalu berpengaruh untuk pemenuhan kebutuhan sehari-hari. Namun, hal ini masih sangat bermanfaat untuk memenuhi kebutuhan ringan seperti memenuhi uang saku sekolah anak.

c. Dampak Lingkungan

Manfaat paling terlihat bagi lingkungan di sekitar Desa Semamung dengan adanya program bank sampah adalah agak berkurangnya tumpukan sampah di beberapa lokasi. Sehingga, lingkungan mereka menjadi lebih bersih dibandingkan sebelum adanya program bank sampah dan pengelolaan terpadu yang dilakukan di Desa Semamung.

\section{PENUTUP}

\section{Kesimpulan}

Penelitian ini menyimpulkan bahwa partisipasi masyarakat Desa Semamung pada program Bank Sampah Sahabat masih relatif sangat rendah. Terlihat sejak pendiriannya di tahun 2018 hingga 2020 ini, hanya sekitar 18 KK saja dari 478 KK yang berperan aktif dalam kegiatan-kegiatan yang diselenggarakan oleh bank sampah tersebut. Hal ini tentunya dipengaruhi oleh beberapa faktor yang cukup signifikan dalam menentukan tingkat partisipasi masyarakat pada program bank sampah Semamung.

Pertama, jumlah anggota keluarga. Semakin banyak jumlah anggota keluarga yang ada, maka akan semakin meningkat motivasi untuk berpartisipasi pada program bank sampah dengan adanya insentif untuk mendapatkan tambahan penghasilan dan adanya anggota keluarga yang dapat membantu untuk memilah sampah yang dihasilkan oleh rumah tangganya. Berikutnya adalah faktor porsi peran yang diberikan oleh pengelola kepada masyarakat dalam pengambilan keputusan juga sangat memengaruhi untuk berpartisipasi dalam program pengelolaan sampah di bank sampah. Semakin besar kesempatan yang diberikan dalam pengambilan keputusan, serta memberikan ide dan gagasan, maka akan semakin besar pula tingkat partisipasi masyarakat.

Kemudian, tingkat keseringan masyarakat dalam memberikan sosialisasi juga akan berpengaruh pada tingkat partisipasi masyarakat yang mengharapkan adanya sosialisasi yang sangat masif. Lalu, sosialisasi yang dilakukan oleh pemerintah dan tokoh masyarakat yang dihormati oleh masyarakat juga turut memengaruhi efektivitas dalam memotivasi masyarakat untuk berpartisipasi. Pengelola Bank Sampah Sahabat pada dasarnya, cukup menyadari akan pentingnya sosialisasi yang merata tentang program bank sampah karena sampai saat ini sosialiasi terkait bank sampah masih belum bisa dilaksanakan secara optimal, sehingga banyak masyarakat yang hanya pernah mendengar, tetapi tidak mengetahui proses berjalannya bank sampah ini. Masyarakat tersebut juga masih dengan mudahnya membuang sampah di sekitar bantaran aliran sungai, seperti di bawah kolong jembatan Desa Semamung.

Selanjutnya, jenis kelamin, usia, dan pengetahuan masyarakat sangat berpengaruh dalam menentukan tingkat partisipasi masyarakat dalam keberlanjutan pengelolaan Bank Sampah Sahabat di Desa Semamung. Biasanya, perempuan lebih banyak berperan aktif dalam pengelolaan sampah yang disalurkan kepada bank sampah. Selain itu, kebanyakan dari masyarakat yang aktif, biasanya didominasi oleh orang-orang yang masih berusia muda, terutama remaja yang menjadi relawan dari kegiatan-kegiatan bank sampah. Terakhir adalah pengetahuan. Semakin baik pengetahuan masyarakat terkait peran dan fungsi bank sampah yang berdampak pada kebersihan lingkungan dan kesehatan, maka akan semakin besar pula dorongan mereka untuk berpartisipasi pada kegiatan bank sampah.

\section{Saran \\ Ada beberapa saran yang dapat digunakan sebagai salah satu masukan yang untuk}


mengembangkan bank sampah di Desa Semamung, di antaranya:

1. Bagi pihak pengelola bank sampah diperlukan sosialisasi yang optimal terkait peran dan fungsinya untuka masyarakat desa dan dibutuhkan tindakan yang nyata untuk memotivasi masyarakat berpartisipasi dalam kegiatan pengelolaan bank sampah. Pengelola juga harus lebih kreatif dalam menemukan dan mengimplementasikan ide dan gagasan terkait pengolahan sampah yang sudah terkumpul dan terpilah agar dapat menjadi insentif bagi pengelolaan sampah yang lebih baik.

2. Bagi Pemdes juga dibutuhkan pendekatan lebih terhadap pelaku-pelaku yang menjalankan bank sampah agar program ini dapat berjalan sebagaimana mestinya, misalnya dengan membuat Peraturan Kepala Desa (Perdes) Tentang Sistem Pengilahan Sampah dari Rumah Tangga yang berkoordinasi dengan para Ketua Rukun Tetangga (RT) atau Rukun Warga (RW) di wilayah Desa Semamung.

3. Bagi pengelola bank sampah juga perlu memperhatikan penunjang dari bank sampah itu sendiri dikarenakan masalah utama dari Desa Semamung adalah sampah. Bank sampah tidak serta merta menerima semua jenis sampah tanpa dilakukan pemilahan sampah. Hal penunjang lain juga dapat diperhatikan seperti bangunan, tempat pembelian sampah, dan juga TPA yang memadai untuk sampah-sampah lainnya.

4. Bagi instansi yang terkait dengan bank sampah dalam hal ini adalah Dinas Lingkungan Hidup Kabupaten Sumbawa, disarankan untuk menambah fasilitas pengelolaan sampah. Salah satunya tempat sampah pemilah untuk masyarakat agar kegiatan bank sampah, terutama pemilahan sampah dapat berjalan dengan baik.

\section{REFERENSI}

Arikunto, S. (2010). Penelitian Suatu Pendekatan Praktik. Jakarta: PT. Rineka Cipta

Adiana, P. P. E., \& Karmini, N. L. (2012). Pengaruh Pendapatan, Jumlah Anggota Keluarga dan Pendidikan Terhadap Pola Konsumsi Rumah Tangga Miskin di Kecamatan Gianyar. Jurnal Ekonomi Pembangunan, Vol. 1, No. 1, pp. 39-48. Fakultas Ekonomi Universitas Udayana, Denpasar.

Amien, M.S. (2012). Materi Bidang Sampah I Diseminasi dan Sosialisasi Keteknikan Bidang PLP. Direktorat Pengembangan Penyehatan Lingkungan Permukiman
Dirjen Cipta Karya Kementerian Pekerjaan Umum, Jakarta.

Gunawan, I. (2013). Metode Penelitian Kualitatif: Teori dan Praktik. Jakarta: PT. Bumi Aksara.

Habib, I. (2019). Analisis Pemberdayaan Sampah Melalui Sistem Reduce, Reuse, Recycle dalam Meningkatkan Pendapatan Masyarakat serta Pendapatan Asli Desa untuk Mawujudkan Desa Mandiri dalam Perspektif Ekonomi Islam (Studi pada Desa Trimodadi Kabupaten Lampung Utara). Skripsi Sarjana Program Studi Ekonomi Syariah Universitas Islam Negeri Raden Intan Lampung, Lampung.

Hamid, N. (2013). Pengaruh Faktor Sosial Ekonomi terhadap Pastisipasi Masyarakat dalam Pelestarian Mangrove di Kelurahan Wonorejo Kecamatan Rungkut Kota Surabaya. Swara Bhumi e-Journal Pendidikan, Vol. 2, No. 1, pp. 48-55. Fakultas Ilmu Sosial, Universitas Negeri Surabaya, Surabaya.

Kum. (2020). Dampak Membakar Sampah, Buruk bagi Bumi dan Kesehatan. Diakses dari https://www.inibaru.id/ pada tanggal 29 Desember 2020.

Langinan, S., Tulusan, F., Plangiten, N. (2014). Pengaruh Kondisi Sosial Ekonomi Keluarga terhadap Partisipasi Masyarakat dalam Pembangunan Pendidikan (Suatu Studi di Kecamatan Pulutan Kabupaten Kepulauan Talaud). Jurnal Administrasi Publik, Vol. 4, No. 5. Universitas Sam Ratulangi, Manado.

Laor, P., Suma, Y., Keawdounglek, V., Hongtong, A. (2018). Knowledge, Attitude, and Practice of Municipal Solid Waste Management among Highland Residents in Northern Thailand. Journal of Health Research, Vol. 32, No. 2, pp. 123-131. Thailand.

Manalu, S. P., Chahaya, I., \& Marsaulina, I.

(2013). Faktor-Faktor Yang Berhubungan Dengan Partisipasi Masyarakat Dalam Program Bank Sampah Di Kelurahan Binjai Kecamatan Medan Denai Kota Medan Tahun 2013. Lingkungan dan Keselamatan Kerja, 3(1), 14453

Martinawati, M., Zahri, I., Faizal, M. F. M. (2016). Partisipasi Masyarakat dalam Pengelolaan Sampah Rumah Tangga: Sebuah Studi di Kecamatan Sukarami Kota Palembang. Jurnal Penelitian Sains, Vol. 18, No. 1, pp. 14-21. Fakultas Ilmu Matematika dan Ilmu Pengetahuan Alam Universitas Sriwijaya, Palembang. 
Maulina, A. S. (2012). Identifikasi Partisipasi Masyarakat Dalam Pemilahan Sampah Di Kecamatan Cimahi Utara Serta Faktor Yang Mempengaruhinya. Journal of Regional and City Planning, 23(3), 177196.

Moleong, L (2014). Metodologi Penelitian Kualitatif Edisi Revisi. PT. Remaja Rosda Karya, Bandung.

Nurbaiti, S. R., \& Bambang, A. N. (2017). Faktor faktor yang Mempengaruhi Partisipasi Masyarakat dalam Pelaksanaan Program Corporate Social Responsibility (CSR). In Proceeding Biology Education Conference (Vol. 14, No. 1, pp. 224-228).

Notoatmodjo, S. (2010). Promosi Kesehatan Teori dan Aplikasi. Jakarta: Rineka Cipta.

Novianty, M. (2013). Dampak Program Bank Sampah terhadap Sosial Ekonomi Masyarakat di Kelurahan Binjai, Kecamatan Medan Denai, Kota Medan. Jurnal Welfare State, Vol. 2, No. 4, pp. 1-16.

Posmaningsih, D.A. (2016). Faktor-faktor yang Mempengaruhi Partisipasi Masyarakat dalam Pengelolaan Sampah Padat di Denpasar Timur. Jurnal Skala Husada: The Journal of Health, Vol. 13, No. 1, pp. 59-71.

Ratiabriani, N. M., \& Purbadharmaja, I. B. P. (2016). Partisipasi Masyarakat dalam Program Bank Sampah: Model Logit. Jurnal Ekonomi Kuantitatif Terapan, 9(1), 228346.

Saputro, Y. E., Kismartini, K., \& Syafrudin, S. (2015). Pengelolaan Sampah Berbasis Masyarakat Melalui Bank Sampah. Indonesian Journal of Conservation, 4(1).

Satria, L. D. S. (2014). PEMIMPIN PELOPOR SEBAGAI FAKTOR PENGGERAK PARTISIPASI MASYARAKAT DALAM PROGRAM BANK SAMPAH DI RW. 14 KELURAHAN TAMANSARI KECAMATAN BANDUNG WETAN KOTA $B A N D U N G$ (Doctoral dissertation, Universitas Pendidikan Indonesia).
Slamet, Y. (2014). Pembangunan Masyarakat Berwawasan Partisipasi. Surakarta: Sebelas Maret University Press.

Sufianti, E., Ramdani, D.F. (2020). Rintisan Social Enterpreneurship dalam Menangani Permasalahan Sampah Rumah Tangga (Studi Kasus Bank Sampah Pelangi Galaxy). SeTIA Mengabdi-Jurnal Pengabdian kepada Masyarakat, Vol. 1, No. 1, pp. 39-47. STIA LAN Bandung, Bandung.

Sugiyono. (2016). Metode Penelitian Kuantitatif, Kualitatif dan R\&D. Bandung: PT Alfabet.

Suryani, A. S. (2014). Peran bank sampah dalam efektivitas pengelolaan sampah (studi kasus bank sampah Malang). Jurnal Aspirasi, 5(1), 71-84.

Tanod, S. T., Rengkung, M. M., \& Tondobala, L. (2014). Partisipasi Masyarakat Kecamatan Madid terhadap Program Pengelolaan Sampah Kota Bitung. Sabua, 263-272.

Tansatrisna, D. (2014). Persepsi dan Partisipasi Masyarakat dalam Pengelolaan Sampah Rumah Tangga. Bogor: Institut Pertanian Bogor.

Yuliana, I., Wijayanti, Y. (2019). Partisipasi Masyarakat pada Program Bank Sampah. HIGEIA (Journal of Public Health Research and Development), 3(4), 545-555.

\section{Internet}

PTM Kabupaten Pringsewu. (2019). Dampak Pencemaran Udara (Polusi Udara) Terhadap Penyakit Hipertensi. Diakses dari http://www.p2ptm.kemkes.go.id/ pada tanggal 29 Desember 2020.

Ekonomi Bisnis. (2019). Timbulan Sampah Nasional Capai 64 juta ton per Tahun". https://ekonomi.bisnis.com/read/20190221 /99/891611/timbulan-sampah-nasionalcapai-64-juta-ton-per-tahun, diakses pada 28 Juli 2020. 